\title{
THINKING TOGETHER DIGITALIZATION AND SOCIAL INNOVATION IN RURAL AREAS: AN EXPLORATION OF RURAL DIGITALIZATION PROJECTS IN GERMANY
}

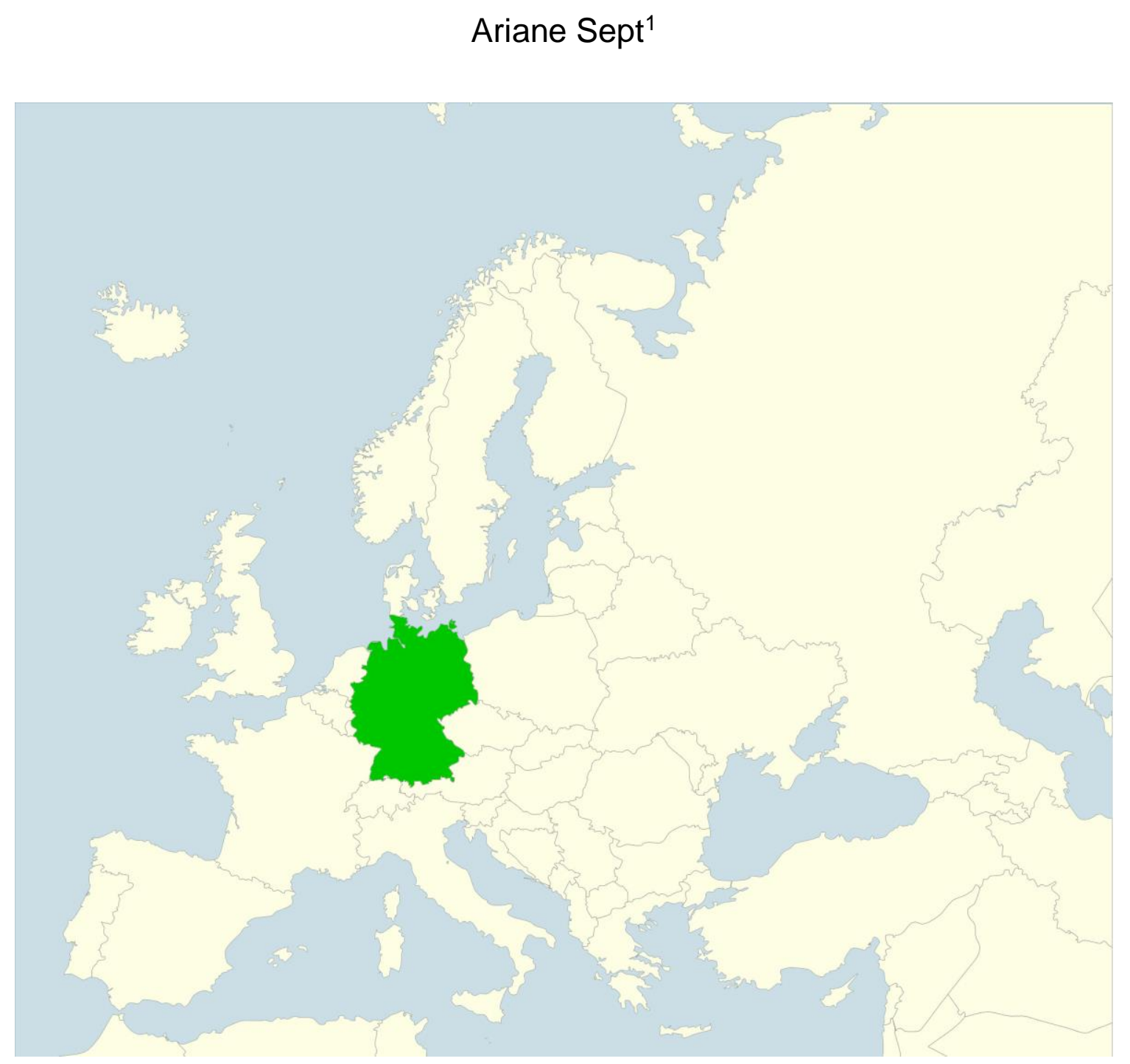

${ }^{1}$ Dr. Ariane Sept, Research Fellow at Leibniz Institute for Research on Society and Space, Erkner, Germany; email: ariane.sept@leibniz-irs.de, ORCID: 0000-0002-8691-1950 


\begin{abstract}
Digitalization and social innovation are often discussed separately and without any spatial reference or in relation to cities, although newer works show the importance of social innovation also for rural areas. Existing digitalization projects illustrate the potential of digital technologies for rural development. Current debates on smart villages refer to both digitalization and social innovation but still in a rather unsystematic way. The paper seeks to think together digitalization and social innovation in rural areas more systemically and proposes to conceptually connect them with the help of sensitizing concepts, which are developed out of debates on social and digital social innovation. Along these concepts, the paper explores rural digitalization projects in Germany. On the one hand, this highlights the spectrum of these initiatives and, on the other hand, provides a framework under which digitalization and social innovation can be analyzed and smart villages may be supported systematically.
\end{abstract}

Keywords: smart villages, digital social innovation, rural development

Abstract: Digitalisierung und soziale Innovationen werden häufig getrennt voneinander und ohne räumlichen Bezug oder in Bezug auf Städte diskutiert, obwohl neuere Arbeiten die Bedeutung sozialer Innovationen auch für ländliche Räume zeigen. Bestehende Digitalisierungsprojekte veranschaulichen zudem das Potenzial digitaler Technologien für ländliche Entwicklung. Aktuelle Debatten zu Smart Villages beziehen sich sowohl auf Digitalisierung als auch auf soziale Innovationen, doch ist dies noch eher unsystematisch. Der Artikel will Digitalisierung und soziale Innovationen im ländlichen Raum systematischer zusammenzudenken und schlägt vor, sie mit Hilfe von Sensibilisierungskonzepten, die aus Debatten über soziale und digitale soziale Innovationen entwickelt werden, konzeptionell zu verbinden. Entlang dieser Konzepte werden anschließend ländliche Digitalisierungsprojekte in Deutschland untersucht. Damit wird zum einen das Spektrum dieser Initiativen aufgezeigt und zum anderen ein Rahmen vorgeschlagen, mit dem Digitalisierung und soziale Innovationen analysiert und Smart Villages systematisch gefördert werden können.

Schlagwörter: smarte Dörfer, digitale soziale Innovationen, ländliche Entwicklung

\title{
1. Introduction
}

Digitalization and social innovation (SI) are widely discussed in scientific literature, especially regarding urban areas but, recently, also within debates on smart villages. However, the two topics often remain disconnected since "in the current literature, there is an emphasis on either technology or social structure and a limited understanding of the interactions between them and the emergent nature of socio-techno practices" (Meijer \& Bolívar, 2016, p. 404). Sometimes digitalization and social innovation are even considered as alternatives to one another, arguing that "SI represents an alternative to economic and technology-oriented approaches to urban development" (Nyseth \& Hamdouch, 2019, p. 1).

Both digitalization and social innovation gained political and scientific attention also regarding rural areas, with a growing body of grey literature and policy papers (e.g., ENRD, 2018a,b,c Williger \& Wojtech, 2018), and a growing number of scientific publications (e.g., Lytras, Visvizi, \& Mudri, 2019; Naldi, Nilsson, Westlund, \& Wixe, 2015 or the Special Issue 2019 in this journal). The idea of smart villages is in the center of these debates, where current publications, however, often focus on ICT as part of innovation in production and distribution of goods and services (e.g., Martin \& Tulla, 2019) or understand digitalization as a driver of innovation in a socio-economic sense (e.g., levoli, Belliggiano, Marandola, Milone, \& Ventura, 2019). The present paper argues that in rural areas, social innovation and digitalization are often developing side by side as digitally supported social-innovation initiatives but it is still unclear how to describe such initiatives and 
how they fit in current debates on social innovation. Thus, main question of the article is how to conceptually connect digitalization and social innovation in rural areas.

Questions regarding implications of digitalization on social life date back to the early 1970s. Today, Robert Wachal is mentioned as the first author who wrote about "digitalization of society" in 1971 (see Brennen \& Kreiss, 2016, p. 560). While the notion digitization means "the material process of converting analog streams of information into digital bits" (Brennen \& Kreiss, 2016, p. 556), digitalization, as used in this article, broadly refers to "the structuring of many and diverse domains of social life around digital communication and media infrastructures" (Brennen \& Kreiss, 2016, p. 560).

Digitalization is based on technological innovation, and several technological innovations lead to broader digitalization; (broadband) internet as well as mobile and stationary devices are accessible to most of the people not only in Western Countries. Admittedly, broadband supply in rural areas in some countries such as Germany remains unsatisfactory, and some authors argue that an urban-rural digital divide has been developing (see Salemink, Strijker, \& Bosworth, 2017) or even widening (Townsend, Wallace, \& Fairhurst, 2015, p. 172). However, "state programmes should devise digitalization strategies that go far beyond expanding digital infrastructure across the country" (Matern, Binder, \& Noack, 2019, p. 12).

Digital technology and devices such as broadband and smart phones have of course spread to rural areas, but "the application and usability of ICT in the context of a village remained underdiscussed in the literature" (Visvizi \& Lytras, 2018, p. 1). Visvizi \& Lytras (2018) used the notion smart village to open a debate on information and communication technology in villages. The notion is problematic in that smart village is not exclusively connected to technological issues but stands also for "climate-smart villages and climate-adaptive rural development" (Seidler, Sharma, \& Telwala, 2016) or refers to comprehensive rural development (e.g., Soligno, Scorza, Amato, Casas, \& Murgante, 2015). In Europe, smart village is closely connected to European policy. In 2010, the European Union has been introducing the term smart next to sustainable and inclusive as part of its economic growth strategy Horizon 2020 (Naldi et al., 2015, p. 90). Regarding rural areas as part of the EU strategy, "smart development is not a one size-fit-all concept and its application in rural contexts needs to be combined with a placebased approach adjusted to fit the specifics of rural contexts and linkages" (Naldi et al., 2015, p. 99). In 2017, the European Union launched the Action for Smart Villages, out of which also The European Network for Rural Development (ENRD) has been established with Smart Villages as one of its thematic sub-groups. Part of the EU activities has also been the Smart Villages Pilot Project, which has been presented as a definition for smart villages in February 2019. Here, too, emphasis is placed on the improvement of the villages' "economic, social and/or environmental conditions, in particular by mobilizing solutions offered by digital technologies" (ECORYS, 2019, pp. 12-13).

The European approaches to smart villages show strong references to digital technologies and social innovation; but as Slee mentioned, these are "two rather separate discourses that frame the thinking and policy development around smart villages" (Slee, 2019, p. 635). They are "founded on an idea of technologically driven development on one hand and on the other built around bottom up community action" (Slee, 2019, p. 647). However, instead of playing both concepts off against each other, these debates can be understood as an invitation to think together social innovation and digitalization more systematically.

To do so, the paper continues with the methodological approach (section 2), and then presents a literature review on social and digital social innovation, elaborating sensitizing concepts (section 3). In section 4, digitalization projects in rural Germany are explored along these sensitizing concepts. Subsequently, the findings are reconnected to the debates on social innovation and smart villages, and critically reflected regarding the limitations of this research (section 5). The paper ends with some concluding remarks highlighting the main findings (section 6). 


\section{Methodological approach}

The paper is part of an ongoing research project and presents the findings of the exploratory phase. The aim of this phase was twofold: (1) to connect debates on social innovation with digitalization in rural areas, and (2) to select five cases for in-depth case studies in a following phase.

Understanding exploratory research as broad but intentional and systematic data collection (Stebbins, 2008) sensitizing concepts (Blumer, 1954) are a way to structure the data collection. Based on a literature review on social and digital social innovation, a sensitizing conceptual framework has been elaborated to approach the field of digitalization projects in rural areas. These sensitizing concepts are not to be regarded as definitive but are intended to provide guidance as „sensitizing concepts merely suggest directions along which to look” (Blumer, 1954, p. 7). For studying an unknown terrain, sensitizing concepts help to provide clues and suggestions for data collection and analyzes.

Data collection started with the creation of a database of projects that gave the impression to be candidates for being a digitally supported social-innovation initiative in rural Germany. This was done in three ways: 1 . By a desktop research using search engines with keywords (smart village, digital village, digitalization and rural), we figured out projects and initiatives in rural Germany that had a professional online presentation or were presented by the media. 2 . By reviewing winners of competitions that honor innovative villages such as "Our village has a future" (Unser Dorf hat Zukunft), "Neuland", "Germany - country of ideas" (Deutschland - Land der Ideen) or "Pithy Village" (Kerniges Dorf), we found projects that won a prize for an especially innovative idea on how to deal with digitalization. 3 . Visiting practice related events and congresses allowed us to find some smaller projects dealing with digitalization and confirmed the innovativeness of projects which had been found with the help of the other two search strategies. By doing so (between January and April 2019), we found 59 projects and initiatives dealing with digitalization in rural areas all over Germany. Some of the projects included several villages without covering another spatial entity (e.g., a whole county or administrative unit), therefore, we had 69 entries in the database. For these, data has been collected regarding location and spatial reference level; project aim, content, and duration; responsible actors; funding; references and contacts, and references to the given public attention, such as media articles or competitions.

We then analyzed all these 69 entries along the sensitizing concepts (1); and (2) applied categories of rurality and peripherality to all of them. For later in-depth case studies, we were looking for villages with a maximum of 1.500 inhabitants, categorized as "rural and peripheral" (according to BMVI, 2019) and "shrinking" or "with no clear direction of development" (according to BBSR, 2017). Furthermore, we wanted them to have different characteristics within the sensitizing concepts and to be in different parts of Germany. Before the final selection, semistructured, exploratory interviews were conducted with apparently central actors of eight projects to have a first check of our sensitizing concepts.

This procedure allowed us to develop a preliminary conceptual framework presenting findings on digitalization projects in Germany, along the sensitizing concepts and integrating them into current debates on social innovation.

\section{Social and digital social innovation}

Research on social innovation has been growing in different disciplines and fields of research (Howaldt \& Schwarz, 2019; Moulaert, MacCallum, \& Hillier, 2013; Mulgan \& Pulford, 2010; Rüede \& Lurtz, 2012), with an exponentially increasing number of published papers since 2003 (van der Have \& Rubalcaba, 2016, p. 1926). While some disciplines, especially sociology, have a long tradition of researching social innovation among different kinds of innovation (Gillwald, 2000; e.g. Ogburn, 1964; Zapf, 1989) others, in particular urban planning and development started discussing social innovation only during the last 20 years (Christmann, lbert, Jessen, \& Walther, 2016; Jessop, Moulaert, Hulgård, \& Hamdouch, 2013; Moulaert, MacCallum, Mehmood, \& Hamdouch, 2013; e.g. Moulaert \& Sekia, 2003; Nyseth \& Hamdouch, 2019; van Dyck \& van den Broek, 2013). Today, urban and regional development are considered one of the main 
research fields for social innovation (Howaldt \& Schwarz, 2019, p. 7; van der Have \& Rubalcaba, 2016, p. 1927). Current topics are for example, "the concept of social innovation (SI) as a potentially transformative factor in urban planning and local development" (Nyseth \& Hamdouch, 2019, p. 1), or conflicts in the implementation of social innovation in urban planning and development (Christmann, 2019).

The vast literature on social innovation shows "a variety of conceptual approaches" (Christmann, 2019 , p. 3) but reveals also the common understanding that social innovation is mainly seen 1) as an urban issue, and 2) as an alternative to technical and economic innovations. Only recently also social innovation in rural areas gained attention; and digital technology entered social innovation discourse under the notion digital social innovation. In the following, both research branches are briefly presented to elaborate sensitizing concepts as a basis for further investigation.

\subsection{Social innovation in rural areas}

Between different disciplines - in particular, urban planning and sociological research - there are still some significant differences in the basic understanding of social innovation. Two of these differences are worth to be considered in order to get a deeper understanding of social innovation and digitalization in rural areas: first, the relation between social innovation and social change; and second, the spatial level of reference.

Regarding the relation between social innovation and social change in urban planning debates, it seems clear that "the aim of SI is social change" (Nyseth \& Hamdouch, 2019, p. 2). According to sociological discussions, however, the "process of social innovation has to be seen as a process of social change" (Howaldt \& Schwarz, 2016, p. 58). Instead of aiming at social change, as Nyseth and Hamdouch suggested, social innovation is seen as part of social change, which means there is no social innovation without social change. Such a perspective is closely connected to the distinction between innovation and invention as stressed already by Schumpeter (Schumpeter, 1911), according to whom an invention becomes an innovation only in case of its diffusion. Something simply new is not yet an innovation. For social innovation, this means the diffusion of new ideas leads to new practices, which are continuously negotiated, interpreted, and adopted in different places (Christmann, 2011, p. 200). Such novel practices shall be understood as social innovation.

At this point, the second difference comes into play: the spatial level of reference. Similar to the political discourse about social innovation that "approaches development issues as deterritorialized management questions" (van Dyck \& van den Broek, 2013, p. 131), also sociological research on social innovation is often separated from spatial considerations. On the other side, local development and planning studies consider social innovation "strongly related both to spatial planning and local development approaches" (Nyseth \& Hamdouch, 2019, p. 2). This discourse is mainly concentrated on urban areas since the "majority of the case studies were located in urban neighborhoods with social exclusion problems in Europe" (Hamdouch \& Galvan, 2019, p. 31). Reasons for this strong urban focus might be on the one hand the traditional idea of innovation as expression of progress in cities which dates back to the $19^{\text {th }}$ century (see Löw \& Sept, 2020). On the other hand, innovative actions especially in structurally weak regions "only rarely came into the focus of a wider mass media discourse" (Christmann, 2017, p. 372), which is dominated by images such as "dying villages" or future "empty landscapes" (Christmann, 2017, p. 365).

Nonetheless, social scientists started to acknowledge social innovations also in rural regions (e.g. Bock, 2016; Christmann, 2017; Fink, Lang, \& Richter, 2017; Noack \& Federwisch, 2019; Richter, 2016), claiming that SI is "not only a task for individual and disadvantaged rural areas but a common concern" (Bock, 2016, p. 570). This relatively new interest is furthermore based on the observation that "some local actors in rural regions have started taking up innovative ideas, experimenting with new solutions and slowing down the "downward spiral"' (Christmann, 2017, p. 365). New solutions here can also mean new "methods of arranging ideas, sometimes not even new" (Butkeviciene, 2009, p. 84). Thus, we must look at new ideas and their combination as well as new combinations of ideas, practices, and structures. 
A central issue in literature concerns the question "where new impulses for rural regions originate" (Noack \& Federwisch, 2019, p. 95), and, thus, who are the driving actors. Traditionally, they "are classified into broad categories; for example, there are top-down and bottom-up or grassroots innovations" (Angelidou \& Psaltoglou, 2017, p. 114). In urban areas, special attention has been paid to grassroots innovations, actor constellation in bottom-up activities (see Christmann, 2019) or planning professionals in a broad sense (see Christmann, Ibert, Jessen, \& Walther, 2019) as drivers of social innovation. Research on social innovation in rural areas focuses on the origin of main actors in terms of urban-rural linkages, intermediaries, or external factors (Noack \& Federwisch, 2019) as well as on social entrepreneurs (Richter, Fink, Lang, \& Maresch, 2020) or elderly people (Noack, 2017).

\subsection{Digital social innovation}

Research on social innovation was initially driven by the desideratum to expand the idea of innovation from a technological and economic view to a more social understanding. The abovementioned distinction between innovation and invention is based on research on economic and technological innovations; and still social and technical or technological innovation are often analyzed separately. In urban planning debates, social innovation is sometimes even considered an alternative to technology-oriented urban development approaches (Nyseth \& Hamdouch, 2019 , p. 1). Such considerations as well as large parts of social innovation research have been often driven by a "politico-ideological ambition [...] to mobilize such theories to offer an alternative to the technology-based and business-oriented discourses, which have long dominated innovation and development policy" (Moulaert, MacCallum, \& Hillier, 2013, p. 18). Thus, research on social innovation has been motivated also by the strong belief, that current social challenges cannot be affronted only with the help of technological and economic innovations (see Howaldt \& Schwarz, 2016, p. 95).

Newer research calls for more attention to the connections between social and technological innovation, claiming that "it is becoming increasingly difficult to make the simplification that led us to distinguish between technical and social innovation" (Manzini, 2015, pp. 16-17). Some researchers even assume that it is "difficult to imagine any social innovation nowadays without some element of technology involved" (Angelidou \& Psaltoglou, 2017, p. 115). Sociological research has been observing for a long time that new technologies and business models can only succeed if they are integrated into existing social practices or if they lead to new social practices (Christmann et al., 2016, p. 278). If we understand new social practices as social innovations, this means new technologies and social innovation must be thought together. Thus, for understanding social innovation, we must look at technology because "the more technical systems penetrate society, the faster and more far-reaching will be their impact on the social systems in which they operate" (Manzini, 2015, p. 16).

Works on social innovation in rural areas, indeed, call for more attention on new technologies, because "new technologies may enable citizens to act at low costs" (Bock, 2016, p. 563) and "the use of novel technology offers great opportunities to such areas" (Bock, 2016, p. 569). From a technical sociology perspective, technology is seen as social actor or social institution (see Schulz-Schaeffer, 2007). In such a view, we must consider the role of technology as drivers, agents, or vehicles of social innovation. Consequently, after some time of explicit separation between social and technological innovation debates, we can now observe a new interest in combinations of social and technological innovations, focusing on digital technologies. The notion digital social innovation (DSI) can be understood as an indicator of this tendency. According to the most widespread definition digital social innovation is

"a type of social and collaborative innovation in which innovators, users and communities collaborate using digital technologies to co-create knowledge and solutions for a wide range a social needs and at a scale and speed that was unimaginable before the rise of the internet" (Bria, 2015, p. 9).

In this definition, scale and speed are highlighted as special characteristics of digital social innovations. From a spatial perspective, scale and speed are discursively connected to cities and thus emphasis is again put on cities. Cities are considered 'the place where 'smartness' is born 
and where 'smartness' is left to wither" (Angelidou \& Psaltoglou, 2017, p. 115); and, accordingly, digital social innovation "is particularly active in cities" (Stokes, Baeck, \& Baker, 2017, p. 33).

Once more, as mentioned for social innovation in general, the discourse on digital social innovation is also either de-territorialized or focused on urban areas, with some few exceptions: in her overview on social innovations in rural areas, Butkevičienè mentioned "electronic social innovations", meaning the role of community websites or digital albums (Butkeviciene, 2009, p. 85). In 2018, the European Network for Rural Development published a brochure entitled "Digital and social innovation in rural services" (ENRD, 2018a) presenting various examples such as co-working spaces, homecare or online training in order to show potentials of digital tools for rural areas. Overall, while the body of literature on digital social innovation is slowly growing (e.g., Stokes et al., 2017), empirical insights to digital social innovation in rural areas are still rare.

A second point worth to note in the above-mentioned definition is the emphasis on collaboration, naming "innovators, users and communities" as actors. Digital social innovation research mainly considers the roles or types of citizens (Angelidou \& Psaltoglou, 2017, p. 120) or the interweaving between previously clear roles of users or consumers and producers or innovators. Classic categories such as top-down, bottom-up or grassroots innovations are also relevant in digital social innovation, but they seem to be understood as mainly de-territorialized networks or single organizations (Bria, 2015, pp. 58-59). In their analysis, Bria concluded that "social innovation in Europe is currently done by a few large actors in concert with a large mass of smaller organisations. Nonetheless, the vast majority of communities are not interconnected" (Bria 2015, p. 54).

In contrast to debates on social innovation, discourse on digital social innovation does not focus on driving actors but on interconnections of different actor types; and a research focus on rural areas is still missing.

\subsection{Sensitizing concepts from social and digital social innovation discourse}

Despite the differences between the two research branches, we can filter out four sensitizing concepts, which have, however, different characters in the two branches: 1) the innovative core means the central understanding of social innovation; 2) the spatial reference level means thespatial unit that is mainly analyzed; 3 ) the role of technology asks for the meaning of digital technology for the respective innovation, and 4) the central actor categories describe the categories that are mainly used to analyze or found in these innovations. Table 1 shows an overview of these sensitizing concepts and their characters in the two research branches.

Tab 1. Sensitizing concepts based on the research branches social innovation and digital social innovation. Source: own elaboration

\begin{tabular}{|l|l|l|}
\hline \multicolumn{1}{|c|}{ Research branch } & Social innovation & Digital social innovation \\
\hline Innovative core & $\begin{array}{l}\text { New ideas and their combination; } \\
\text { new combinations of ideas, } \\
\text { practices, and structures }\end{array}$ & $\begin{array}{l}\text { New collaboration with the help of } \\
\text { digital technology, new scale, and } \\
\text { speed }\end{array}$ \\
\hline Spatial reference level & $\begin{array}{l}\text { De-territorialized; cities; } \\
\text { new attention to rural areas } \\
\text { (regions, villages) }\end{array}$ & $\begin{array}{l}\text { De-territorialized (networks or } \\
\text { organizations); cities }\end{array}$ \\
\hline Role of technology & $\begin{array}{l}\text { No specific role or considered as } \\
\text { opposite }\end{array}$ & $\begin{array}{l}\text { Co-creation of knowledge, } \\
\text { solutions for a wide range of } \\
\text { social needs; drivers, agents, or } \\
\text { vehicles }\end{array}$ \\
\hline $\begin{array}{l}\text { Central actor } \\
\text { categories }\end{array}$ & $\begin{array}{l}\text { Bottom-up, top-down, grassroot } \\
\text { initiatives; planning professionals; } \\
\text { intermediaries; elderly; social } \\
\text { entrepreneurs }\end{array}$ & \begin{tabular}{l} 
Innovators, users, communities \\
\hline
\end{tabular}
\end{tabular}




\section{Digitally supported social-innovation initiatives in rural Germany}

In German rural areas, there is already a variety of existing - often experimental - projects that use digital tools. These projects give the impression that rural inhabitants make use not only of new technological possibilities, but rather break with pre-existing ways of acting and combining digital innovations with new social practices to solve problems in their villages. Nevertheless, many of these projects are still relatively young, and in line with the sociological idea that new ideas need a certain diffusion or stabilization to become social innovations we suggest to tentatively call these digitalization projects digitally supported social-innovation initiatives.

\subsection{Innovative core and role of technology}

Digitalization projects in German rural areas deal with manifold topics. However, we found two basic types of initiatives: comprehensive projects dealing with a bunch of topics and single-issue projects.

Comprehensive projects often aim at the creation of digital ecosystems (see ENRD, 2018a, p. 24; Elberzhager, Koch, \& Weitzel, 2018) and are mainly characterized by a predominantly experimental character regarding software development and/or participation in order to find solutions for the most urgent rural problems. Components of such digital ecosystems are "the community, domain specific services (e.g. mobility, health, etc.), a technical platform, the basic infrastructure, and the organisation of all these layers" (ENRD, 2018b, p. 1). Comprehensive projects are often characterized by a top down-bottom up-interplay. Driven by institutions on county or federal state level, problems and possible digital solutions are elaborated within structured participation processes together with different local actors and rural inhabitants.

One example is the Digital Villages project (Elberzhager et al., 2018; Entwicklungsagentur Rheinland-Pfalz e.V., 2017; Fraunhofer IESE, 2020) in Rhineland-Palatinate. In 2015, the Development Agency Rhineland-Palatinate and a Fraunhofer institute started to analyze local needs in three rural pilot project municipalities ("living labs") and, in a second step, to develop a digital platform connecting different applications regarding local supply, mobility and communication. The aim of the project is to show "how digitisation opens up new opportunities for rural areas" (ENRD, 2018b, p. 1) to overcome typical rural problems such as demographic change, insufficient infrastructure, or long distances. The platform with its applications, in particular the community app, is already (as of the end of 2019) used by more than 30 municipalities, some of them also out of Rhineland-Palatinate.

Another exemplary comprehensive project is called Smart Country Side (OstWestfalenLippe, 2019) and started in 2016 in the counties Höxter and Lippe (North Rhine-Westphalia), covering 26 villages. It focuses on mobility, e-governance, e-participation, and communication for civil society. A team of professionals from both counties started so-called village conferences to understand local needs and ideas. Out of these workshops, five topics were elaborated to be addressed with the help of digital tools: communication platform (digital market place, news, etc.), caring (offering and finding help), faith (online church, pilgrim routes, etc.), living (connecting building owners, smart homes, etc.), and digital education. Under this umbrella, different projects have been developed in the participating villages. One core measure was the formation and education of so-called village digital experts as multiplicators. Some of the involved villages furthermore also decided to use the above-mentioned platform Digital Villages.

In contrast to comprehensive projects, single-issue projects are focused on only one field, such as mobility, retail, tourism and local economy, remote working, administration, communication, or health care. Digital technology is used as a tool to overcome a specific problem. Remote working, for instance, is one of the topics discussed for years as a chance for rural areas (e.g., Akademie für Raumforschung und Landesplanung, 1987). However, co-working spaces and home office regulations have been experienced mainly in big cities. Only recently, new ideas come into being also in rural areas, examples are the co-working space in the small village Klein Glien in Brandenburg that connects vacation and work as workation (Coconat, 2020), or a pilot project of temporary using a vacant building in the rural municipality Prüm (Rhineland-Palatinate) as coworking space (Entwicklungsagentur Rheinland-Pfalz e.V., 2020). 
A common problem in villages is mobility, as public transport is often insufficient. Tackling this problem actively, there are several projects that experiment with car or ridesharing managing them with the help of digital tools. One example is the village e-car in the Brandenburg village Barsikow (Dorfmobil Barsikow, 2020). Supported with funding from the county, a village association bought an e-car which now serves for village internal car sharing. Booking, payment and administration is managed with a smart phone application. Another example of single-issue projects is the application Knoop (Sourceboat, 2020), initially developed in the small village Löwenstedt (Schleswig-Holstein) that gives villagers the possibility to individually switch on street lighting with their smart phones - a direct reaction to the problem of darkness in the village after street lights are switched off during the night.

The Loikum glass fiber model is an example for a single issue project that addresses shortness in digital infrastructure: inhabitants of the small village Loikum developed a technology and organization model for small village communities to install glass fiber cables on their own with the help of a specifically modified plow. The model, which can also be adapted by other villages, consists of four steps: finding a network provider; founding of a group of installers; ploughing in of the lines in own contribution and handing over to the network provider (Loikumer Glasfaser Modell, 2020).

All these initiatives are mainly not totally new, but their innovativeness lie in new combinations, new practices, or new uses. As noticed above, co-working has been experienced for some years in big cities, examples in rural areas go beyond these known models by combining, for instance, co-working and vacation. Likewise, carsharing has been operating for some years in bigger cities, however, mainly organized by commercial suppliers or privately organized with private cars. In rural areas, we found carsharing that is bottom-up organized by local associations. Installation of glass fiber cables is also not new as such, however, rural communities developed not only a new way of installation with a plow (a typical rural device) but also a new management and organization model that makes them more independent, and help overcoming the problem of broadband connectivity, especially outside village centers.

The role of digital technology in comprehensive projects is that of an opportunity to address a variety of rural problems and challenges. Digital tools are in a constant development process, and thus the process appears as important as a result. In contrast, the role of digital technology in single-issue projects is that of a tool which helps to overcome a specific problem.

\subsection{Spatial reference level}

Digitally supported social-innovation initiatives happen all over Germany. However, we found more projects in the Western German states than in the Eastern part, where they strongly concentrate in Brandenburg. The analyzed initiatives take place on different spatial and administrative levels: village level, municipal level and inter municipal level, or rather county level. Circa half of the projects (30) covered more than a village: either a county, a loose or fix association of several villages, or a small town. The other half was based in villages or small municipalities. Few projects did not have a concrete spatial reference level but covered a very generic rural area. These are related to health issues such as telemedicine in the Lindlar region (DVS, 2017, p. 15) or internet-based psychotherapy in and around Lohr am Main (Christ, 2019). For some projects, the spatial reference level can be hardly defined: the above-mentioned Digital Villages platform is one of these. Although it has been initially developed with three specific municipalities, the platform can now be used and customized for single villages or municipalities anywhere in rural areas.

\subsection{Central actor categories: Driving actors}

Even if it could be assumed that different actors and actor groups play a role in different stages of the analyzed initiatives, we initially only filtered out the driving actors. Among them we identified three types of driving actors: 1) visionary and creative actors, 2) problem solving actors and 3) professional actors. 
Visionary and creative actors: As visionary and creative actors, we describe people who are motivated by an idea or a broader vision, willing to experience new ideas and open to experimental, often flexible projects. Visionary and creative actors sometimes also have commercial interests (such as creation of a new business in a village), are driven by personal interests (such as dreaming to live a rural life) or follow an intrinsic motivation to make the village a better place. In many cases, visionary and creative actors are new village inhabitants or return migrants. For these actors, digital technology opens a window of opportunity to realize a broader vision. The owners of the above-mentioned workation are one example for visionary and creative actors. Based on the Berlin Start-Up scene and driven by the idea of independent work, they were looking for a rural place to live and work together. However, visionary and creative actors are not only young creative or alternative people. Another example is the voluntary mayor of a small village between Berlin and Hamburg who is convinced that digital technology will save the villages' future, strongly believing in community, sharing and autonomous driving.

Problem solving actors: Problem solving actors are people aware of certain problems in their villages, and by trying to solve the specific problems they come across with digital technology as part of a solution to that problem. These bottom-up actors are often engaged as volunteers, such as voluntary mayors, local representatives, local associations, or simply active citizens. Typical projects led by this actor type are single-issue projects, and often have their basis in an "analogue project". An example is a village where inhabitants self-organized a new meeting place or village store to address missing services. Only afterwards, the new place is equipped with free community WiFi or used for digital learning. The developer of the above-mentioned street light app can also be considered a problem solving actor, personally upset by unlit village streets at night, she wrote an application, proposed it to the village community, and after a test phase, it can now be used by all inhabitants.

Professional actors: Professional actors are engaged with digital solutions and/or community development as part of their work. These can be software developers as well as full-time mayors or administrative staff of municipalities, counties, or other territorial administrative units. Furthermore, we saw foundations or civil society organizations as well as business associations, research institutions or universities as driving actors. Projects driven by professional actors are often comprehensive ones. Many projects are characterized by a "top down-bottom up interplay" which means that the driving actor starts with a participation process to understand current needs of the village inhabitants. Based on these needs, digital solutions are developed, locally tested, and adjusted. The above-mentioned platform Digital Villages is one the strongest examples for such a driving actor constellation, driven by a public administration entity in collaboration with an applied research institute.

Boundaries between the three types appear to be flexible and regularly broken during the projects since new actors come in and sometimes become the new driving force. Voluntary actors with a strong approach to problem solving are, for example, looking for professional actors to get funding or to directly use professionally developed digital solutions, such as specific applications. In such cases, professional actors might take over the role as driving actors. The other way around is that professional actors also sometimes specifically look for local problem solvers to propose their digital tools or to offer advice.

\section{Discussion: Connecting social innovation and digitalization projects}

Our findings suggested two types of digitally supported social-innovation initiatives (comprehensive and single-issue) that allow a finer distinction along the sensitizing concepts, revealing similar and different characteristics.

The innovative core appears in both types similar to other social innovations in rural areas. The initiatives are mainly about new combinations of ideas such as work and vacation or carsharing and villages, and consequently also new practices. Some regard new uses such as using a plow for broadband laying or utilizing smart phones for operating streetlights. Different characteristics among the two project types regard the role of technology: while it is basically a tool in single-issue projects, in comprehensive projects digital technology becomes an opportunity and agent to address rural challenges. Comprehensive initiatives as well as single- 
issue projects may be driven by all the three mentioned actor types. However, some connections appear stronger than others. Comprehensive projects had been mainly driven by professional actors, and in a few cases by visionary and creative actors. Problem solving actors mainly guide single-issue projects, which, nevertheless, could be driven also by the two other actor types. In contrast to the social innovation literature, classic categories of bottom-up and top-down become more and more fuzzy. Especially comprehensive projects driven by professional actors are in many cases characterized by a top-down bottom-up-interplay, a kind of continuous feedback loop in both directions. We can take this as an indicator that such rural digitalization projects are similar to digital social innovation, which is characterized by new collaborations and co-creation of knowledge (Bria, 2015; Stokes et al., 2017). The actor types proposed in debates on digital social innovation (innovators, users, and communities) do not appear sharp enough to describe the driving actors in the observed digitally supported social-innovation initiatives, but they might play a role in further stages.

Tab 2. Overview on the sensitizing concepts and their characteristics in digitally supported social-innovation initiatives in rural Germany. Source: own elaboration

\begin{tabular}{|c|c|c|}
\hline Sensitizing concept & Comprehensive projects & Single-issue projects \\
\hline Innovative core & $\begin{array}{l}\text { new combinations, new } \\
\text { practices, or new uses }\end{array}$ & $\begin{array}{l}\text { new combinations, new practices, } \\
\text { or new uses }\end{array}$ \\
\hline $\begin{array}{l}\text { Spatial reference } \\
\text { level }\end{array}$ & $\begin{array}{l}\text { (village), fix or loose village } \\
\text { association, municipality, inter } \\
\text { municipal cooperation, county }\end{array}$ & $\begin{array}{l}\text { village, fix or loose village } \\
\text { association, municipality, inter } \\
\text { municipal cooperation, (county) }\end{array}$ \\
\hline Role of technology & $\begin{array}{l}\text { opportunity to overcome rural } \\
\text { problems, process-oriented } \\
\text { creation of digital ecosystems }\end{array}$ & $\begin{array}{l}\text { tool to overcome a specific local } \\
\text { problem }\end{array}$ \\
\hline Central actor types & $\begin{array}{l}\text { professional actors, visionary } \\
\text { and creative actors, problem } \\
\text { solving actors, often top-down } \\
\text { bottom-up interplay }\end{array}$ & $\begin{array}{l}\text { problem solving actors, visionary } \\
\text { and creative actors, professional } \\
\text { actors, often but not exclusively } \\
\text { bottom-up }\end{array}$ \\
\hline
\end{tabular}

Limitations of this paper already result from the exploratory character of the research which, by its nature, does not provide definite evidence but only a situational picture. Although the sensitizing concepts are rooted in international literature, the empirical research has been limited to rural Germany, which may differ from other European rural areas. More international and comparative research could supplement and verify the findings presented in this paper. Moreover, the findings regarding the spatial reference level, are to some extent affected by a selection bias. As we were explicitly looking for digitalization projects in rural areas, initiatives that had been developed without any spatial reference or in urban areas and then spread to rural areas were not included in the database. The same is true for failed digitalization projects or those with a negative impact on social innovation. Future research should verify the elaborated sensitizing concepts also for such initiatives. Furthermore, this paper only focused on driving actors, which are crucial in the beginning but not the only ones. Even in this exploration, one could see that successful projects need driving actors, but they also need support, and live from their users. To better understand the connections between various actor groups in different project stages, their roles and motivation, and their interaction with digital technology, future in-depth research is needed. 


\section{Conclusion}

The present paper has been showing that social innovation, seen as new combinations or novel practices to develop new solutions for current problems, and digital technology are no opposites in rural areas. Questions of digital competences, new ways of using digital infrastructures (e.g., for village carsharing or for operating streetlights) and new possibilities of organizing rural communities (e.g., with the help of a community app or offering rural co-working options) must be understood as inherent parts of rural development. As shown in section 2, discourse on social innovation and digital social innovation is still concentrated on urban areas or lacks a spatial focus. While current debates on digital social innovation concentrate on technology as means to rapidly co-create knowledge or solutions to a wide range of social needs, we can observe that rural digitalization projects often have the clear focus to offer a solution for a specific problem or to create digital ecosystems.

The approach of exploratory research with the help of sensitizing concepts (Section 2) proved helpful, because it allows to explore and analyze rural digitalization along these concepts, which can be reconnected to scientific discourse on social and digital social innovation. Debates on and policy for smart villages can benefit from this by introducing the same concepts to systematically develop digital social innovation in rural areas. This may happen by parallelly supporting development of digital tools and empowering locally rooted actors on village, municipal or county level to try out new ideas with the potential to address rural challenges.

Further long-term and in-depth research is needed to better understand the mechanisms, structures, and effects of social digital innovations in rural areas; and to analyze the roles and motivations of different actors. Beyond the aims and scope of this paper but worth to note is the risk of dominant professional actors. Today, there is still a variety of driving actors engaged with digitalization in rural areas, but a future dominance of professional actors cannot be excluded. As we know from urban digitalization processes, smart city concepts have been widely criticized for their dependency on (globally acting) IT companies and a new influence of these companies on urban development (see Bauriedl \& Strüver, 2018). Thus, the role of commercially driven interests should be monitored carefully and critically, also in rural areas.

\section{Acknowledgements}

The presented material is part of the ongoing research project "Smart Villagers. Digitalization and social innovations in rural areas", funded and conducted (2019 to 2021) by the Leibniz Institute for Research on Society and Space in Erkner (near Berlin), Germany. My special thanks go to the project leader Gabriela Christmann. A preliminary version of the paper has been presented at Aesop Annual Congress 2019 in Venice and shortlisted at the Aesop Young Academics Best Paper Award. Advice given by the discussants and reviewers has been a great help in sharpening my arguments. My further thanks go to the two unknown reviewers for providing constructive feedback, which was a big support in the revision phase of this manuscript.

Academic references

[1] Angelidou, M. \& Psaltoglou, A. (2017). An empirical investigation of social innovation initiatives for sustainable urban development. Sustainable Cities and Society, 33, 113-125. DOI: 10.1016/j.scs.2017.05.016.

[2] Bauriedl, S. \& Strüver, A., eds. (2018). Smart City - Kritische Perspektiven auf die Digitalisierung in Städten. Bielefeld: Transcript.

[3] Blumer, H. (1954). What is Wrong with Social Theory? American Sociological Review, 19(1), 3-10. DOI: 10.2307/2088165.

[4] Bock, B. B. (2016). Rural Marginalisation and the Role of Social Innovation; A Turn Towards Nexogenous Development and Rural Reconnection. Sociologia Ruralis, 56(4), 552-573. DOI: $10.1111 /$ soru.12119. 
[5] Brennen, J. S. \& Kreiss, D. (2016). Digitalization. In The International Encyclopedia of Communication Theory and Philosophy (pp. 556-566). Hoboken, NJ: Willey-Blackwell. DOI: 10.1002/9781118766804.wbiect111.

[6] Bria, F. (2015). Growing a digital social innovation ecosystem for Europe: DSI final report. Luxembourg: Publications Office.

[7] Butkeviciene, E. (2009). Social innovation in rural communities: methodological framework and empirical evidence. Socialiniai mokslai - Social Sciences, 1, 80-88.

[8] Christmann, G. B. (2011). Soziale Innovationen, Social Entrepreneurs und Raumbezüge. In Jähnke, P., Christmann, G. B. \& Balgar, K., eds., Social Entrepreneurship. Perspektiven für die Raumentwicklung (pp. 193-210). Wiesbaden: VS Verlag für Sozialwissenschaften.

[9] Christmann, G. B. (2017). Analysing Changes in Discursive Constructions of Rural Areas in the Context of Demographic Change: Towards Counterpoints in the Dominant Discourse on "Dying Villages". Comparative Population Studies, 41(3-4), 359-378. DOI: 10.12765/CPoS2017-03en.

[10] Christmann, G. B. (2019). Introduction: Struggling with innovations. Social innovations and conflicts in urban development and planning. European Planning Studies, 4(1), 1-11. DOI: 10.1080/09654313.2019.1639396.

[11] Christmann, G. B., Ibert, O., Jessen, J. \& Walther, U.-J. (2016). Wie kommt Neuartiges in die räumliche Planung? In Rammert, W., Windeler, A., Knoblauch, H. \& Hutter, M., eds., Innovationsgesellschaft heute: Perspektiven, Felder und Fälle (pp. 273-300). Wiesbaden: Springer VS.

[12] Christmann, G. B., Ibert, O., Jessen, J., \& Walther, U.-J. (2019). Innovations in spatial planning as a social process - phases, actors, conflicts. European Planning Studies, 3(1), 1-25. DOI: 10.1080/09654313.2019.1639399.

[13] Elberzhager, F., Koch, M. \& Weitzel, B. (2018). Towards a Digital Ecosystem for Rural Areas: Experiences from Three Years of Development. In Kuhrmann, M. et al., ed., Product-focused software process improvement (pp.98-105). Cham, Switzerland: Springer. DOI: 10.1007/978-3-030-03673-7_7.

[14] Fink, M., Lang, R. \& Richter, R. (2017). Social Entrepreneurship in Marginalised Rural Europe: Towards Evidence-Based Policy for Enhanced Social Innovation. Regions Magazine, 306(1), 6-10. DOI: 10.1080/13673882.2017.11878963.

[15] Gillwald, K. (2000). Konzepte sozialer Innovation [working paper]. Berlin: Wissenschaftszentrum Berlin für soziale Wissenschaften..

[16] Hamdouch, A. \& Galvan, A. (2019). Social Innovation as a Driver of Urban Transformation? The Case of Planning Approaches in the Dominican Republic. Urban Planning, 4(1), 31-43. DOI: $10.17645 /$ up.v4i1.1740.

[17] Howaldt, J. \& Schwarz, M. (2016). Social innovation and its relationship to social change. [SI-DRIVE project paper]. Dortmund: Technische Universität.

[18] Howaldt, J. \& Schwarz, M. (2019). Soziale Innovation. In Blättel-Mink, B., Schulz-Schaeffer, I. \& Windeler, A., eds., Springer Reference. Handbuch Innovationsforschung (pp. 1-17). Heidelberg: Springer.

[19] levoli, C., Belliggiano, A., Marandola, D., Milone, P. \& Ventura, F. (2019). Information and Communication Infrastructures and New Business Models in Rural Areas: The Case of Molise Region in Italy. European Countryside, 11(4), 475-496. DOI: 10.2478/euco-20190027.

[20] Jessop, B., Moulaert, F., Hulgård, L. \& Hamdouch, A. (2013). Social innovation research: a new stage in innovation analysis? In Moulaert, F., MacCallum, D., Mehmood, A. \& Hamdouch, A., eds., The international handbook on social innovation: Collective action, 
social learning and transdisciplinary research (pp. 110-130). Cheltenham (UK), Northampton (Mass.): E. Elgar.

[21] Löw, M. \& Sept, A. (2020). Innovationen in Stadt und Raum. In Blättel-Mink, B. SchulzSchaeffer, I. \& Windeler, A., eds., Handbuch Innovationsforschung. Wiesbaden: VS Verlag für Sozialwissenschaften.

[22] Lytras, M., Visvizi, A. \& Mudri, G. eds. (2019). Smart Villages in the EU and beyond. Emerald studies in politics and technology. Bingley: Emerald.

[23] Manzini, E. (2015). Design, when everybody designs: An introduction to design for social innovation. Design thinking, design theory. Cambridge (Mass.), London: MIT Press.

[24] Martin, A. V. \& Tulla, A. F. (2019). Innovation, Spatial Loyalty, and ICTs as Locational Determinants of Rural Development in the Catalan Pyrenees. European Countryside, 11(4), 517-540. DOI: 10.2478/euco-2019-0029.

[25] Matern, A., Binder, J. \& Noack, A. (2019). Smart regions: Insights from hybridization and peripheralization research. European Planning Studies, 6(1), 1-18. DOI: 10.1080/09654313.2019.1703910.

[26] Meijer, A. \& Bolívar, M. P. R. (2016). Governing the smart city: A review of the literature on smart urban governance. International Review of Administrative Sciences, 82(2), 392-408. DOI: $10.1177 / 0020852314564308$.

[27] Moulaert, F., MacCallum, D. \& Hillier, J. (2013). Social innovation: intuition, precept, concept, theory and practice. In Moulaert, F., MacCallum, D., Mehmood, A. \& Hamdouch, A., eds., The international handbook on social innovation: Collective action, social learning and transdisciplinary research (pp. 13-24). Cheltenham (UK), Northampton (Mass.): E. Elgar.

[28] Moulaert, F., MacCallum, D., Mehmood, A. \& Hamdouch, A. eds. (2013). The international handbook on social innovation: Collective action, social learning and transdisciplinary research. Cheltenham (UK), Northampton (Mass.): E. Elgar.

[29] Moulaert, F. \& Sekia, F. (2003). Territorial Innovation Models: A Critical Survey. Regional Studies, 37(3), 289-302. DOI: 10.1080/0034340032000065442.

[30] Mulgan, G. \& Pulford, L. (2010). Study on Social Innovation. Oxford: SAID Business School.

[31] Naldi, L., Nilsson, P., Westlund, H. \& Wixe, S. (2015). What is smart rural development? Journal of Rural Studies, 40, 90-101. DOI: 10.1016/j.jrurstud.2015.06.006.

[32] Noack, A. (2017). Elderly People in Rural Regions as Promoters of Social Innovations and Changing Knowledge. In Svels, K., ed., Uneven processes of rural change: on diversity, knowledge and justice (pp. 118-119). Kraków: Jagiellonian University.

[33] Noack, A. \& Federwisch, T. (2019). Social Innovation in Rural Regions: Urban Impulses and Cross-Border Constellations of Actors. Sociologia Ruralis, 59(1), 92-112. DOI: 10.1111/soru.12216.

[34] Nyseth, T. \& Hamdouch, A. (2019). The Transformative Power of Social Innovation in Urban Planning and Local Development. Urban Planning, 4(1), 1. DOI: 10.17645/up.v4i1.1950.

[35] Ogburn, W. F. (1964). On Culture and Social Change. Chicago: Phoenix Books; University of Chicago Press.

[36] Richter, R. (2016). Social Innovations in Rural Life Worlds. In Carlow, V. M., ed., Ruralism (pp. 148-155). Berlin: Jovis.

[37] Richter, R., Fink, M., Lang, R. \& Maresch, D. (2020). Social entrepreneurship and innovation in rural Europe. Routledge studies in social enterprise \& social innovation: Vol. 9. New York: Routledge.

[38] Rüede, D. \& Lurtz, K. (2012). Mapping the various meanings of social innovation: Towards a differentiated understanding of an emerging concept. [research paper]. Friedrichshof: Universität für Wirtschaft und Recht. 
[39] Salemink, K., Strijker, D. \& Bosworth, G. (2017). Rural development in the digital age: A systematic literature review on unequal ICT availability, adoption, and use in rural areas. Journal of Rural Studies, 54, 360-371. DOI: 10.1016/j.jurstud.2015.09.001.

[40] Schulz-Schaeffer, I. (2007). Technik als sozialer Akteur und als soziale Institution: Sozialität von Technik statt Postsozialität [working paper] Berlin: Technische Universität.

[41] Schumpeter, J. A. (1911). Theorie der wirtschaftlichen Entwicklung: eine Untersuchung über Unternehmergewinn, Kapital, Kredit, Zins und den Konjunkturzyklus. Leipzig.

[42] Seidler, R., Sharma, G. \& Telwala, Y. (2016). Climate Vulnerability, Water Vulnerability. In Developments in Earth Surface Processes (pp. 279-308). Amsterdam: Elsevier. DOI: 10.1016/B978-0-444-63787-1.00007-X.

[43] Slee, B. (2019). Delivering on the Concept of Smart Villages - in Search of an Enabling Theory. European Countryside, 11(4), 634-650. DOI: 10.2478/euco-2019-0035.

[44] Soligno, R., Scorza, F., Amato, F., Casas, G. L. \& Murgante, B. (2015). Citizens Participation in Improving Rural Communities Quality of Life. In Gervasi, O. \& et al., eds., Computational Science and Its Applications - ICCSA 2015 (pp. 731-746). Cham: Springer. DOI: 10.1007/978-3-319-21407-8_52.

[45] Stebbins, R. A. (2008). Exploratory Research. In Given, L. M., ed., The Sage encyclopedia of qualitative research methods. Los Angeles: Sage. DOI: 10.4135/9781412963909.n166.

[46] Stokes, M., Baeck, P. \& Baker, T. (2017). What next for digital social innovation? Realising the potential of people and technology to tackle social challenges [project report]. Brussel: European Community.

[47] Townsend, L., Wallace, C. \& Fairhurst, G. (2015). 'Stuck Out Here': The Critical Role of Broadband for Remote Rural Places. Scottish Geographical Journal, 131(3-4), 171-180. DOI: $10.1080 / 14702541.2014 .978807$.

[48] Van der Have, R. P. \& Rubalcaba, L. (2016). Social innovation research: An emerging area of innovation studies? Research Policy 45(9), 1923-1935. DOI: 10.1016/j.respol.2016.06.010.

[49] Van Dyck, B. \& van den Broek, P. (2013). Social innovation: a territorial process. In Moulaert, F., MacCallum, D., Mehmood, A. \& Hamdouch, A., eds., The international handbook on social innovation: Collective action, social learning and transdisciplinary research (pp. 131141). Cheltenham (UK), Northampton (Mass.): E. Elgar.

[50] Visvizi, A. \& Lytras, M. (2018). It's Not a Fad: Smart Cities and Smart Villages Research in European and Global Contexts. Sustainability 10(8). DOI: 10.3390/su10082727.

[51] Williger, B. \& Wojtech, A. (2018). Digitalisierung im ländlichen Raum: Status Quo \& Chancen für Gemeinden. [white paper]. Nürnberg: Fraunhofer Institut.

[52] Zapf, W. (1989). Über soziale Innovationen. Soziale Welt, 40(1-2), 170-183.

Other sources

[53] Akademie für Raumforschung und Landesplanung (Ed.) (1987). Räumliche Wirkungen der Telematik. Hannover: Vincentz.

[54] BBSR (2017). Wachsen und Schrumpfen von Städten und Gemeinden im bundesweiten Vergleich. https://gis.uba.de/maps/resources/apps/bbsr/index.html?lang=de.

[55] BMVI (2019). Regionalstatistische Raumtypologie (RegioStaR).

https://www.bmvi.de/SharedDocs/DE/Artikel/G/regionalstatistische-raumtypologie.html.

[56] Christ, P. (2019, January 8). Der Therapeut am Laptop. Main Post.

[57] Coconat (2020). Coconat - A Workation Retreat. http://coconat-space.com/de. 
[58] Dorfmobil Barsikow (2020). Dorfmobil Barsikow - Wir teilen uns ein Elektroauto. http://dorfmobil.barsikow.de.

[59] DVS (2017). Themenheft „Digitale Lösungen für's Land“. LandInForm (3).

[60] ECORYS (2019). Pilot project smart eco-social villages: Presentation. Brüssel.

[61] Entwicklungsagentur Rheinland-Pfalz e.V. (2017). \#Landleben- Unsere Zukunft im digitalen Dorf. https://www.demografie-portal.de/SharedDocs/Downloads/DE/GutePraxis/DigitaleDoerfer.pdf?_blob=publicationFile\&v=1.

[62] ENRD (2018a). Digital and social innovation in rural services. Luxembourg: Publications Office of the European Union.

[63] ENRD (2018b). Digital Villages Germany: Working Document. European Network for Rural Development website: https://enrd.ec.europa.eu/sites/enrd/files/tg_smart-villages_casestudy_de.pdf.

[64] ENRD (2018c). German strategies for digitising rural areas. https://enrd.ec.europa.eu/sites/enrd/files/enrd_publications/digital-strategies_casestudy_de.pdf.

[65] Entwicklungsagentur Rheinland-Pfalz e.V. (2020). Schreibtisch in Prüm. https://schreibtischinpruem.de.

[66] Fraunhofer IESE (2020). DIGITALE DÖRFER - VOM LAND FÜRS LAND. https://www.digitale-doerfer.de.

[67] Loikumer Glasfaser Modell (2020). Loikumer-Glasfaser-Modell. http://www.derglasfaserbauer.de.

[68] OstWestfalenLippe (2019). Smart Country Side. https://www.owl-morgen.de/projekte/smartcountry-side.

[69] Sourceboat (2020). Knoop - Beleuchtung bei Bedarf. https://knoop.sh. 